
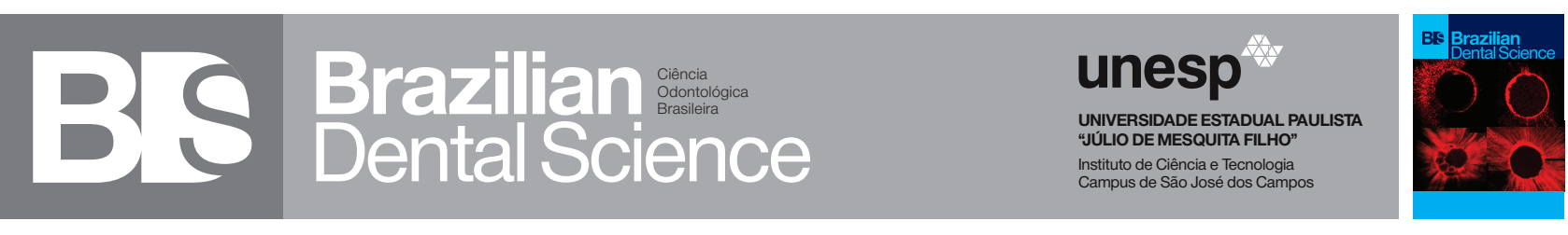

\title{
White spots on tooth enamel in mixed dentition
}

\author{
Manchas brancas em esmalte dentário na dentição mista
}

Ana de Lourdes SÁ DE LIRA ${ }^{1}$, Nayra Rafaelle Fernandes da SILVA ${ }^{1}$

1 - State University of Piauí - UESPI - School of Dentistry - Department of Pediatric Dentistry and Orthodontics - Area of Integrated Clinic - Parnaíba - PI - Brazil.

\section{ABSTRACT}

Aim: To determine the prevalence, predisposing factors of white spots on enamel and the effectiveness of treatment using the microabrasion technique. Method: A study was developed in children between the ages of 6 and 12 of both genders, enrolled in 3 municipal public schools. Epidemiological questionnaire was applied to the participants and parents or guardians to investigate the predisposing factors of the lesions on permanent teeth during the mixed dentition. Oral examination of the children was carried out, and for those children in whom white spot lesions were found, dental treatment was provided by the microabrasion technique in the incisors and/ or first permanent molars to prevent the evolution to a caries lesion with cavitation, since the enamel structure was damaged. Results: The majority of the sample had from $1 \%$ to $24 \%$ of the enamel affected by the white spots. The possible predisposing factors of white spots were systemic infections, trauma or caries with pulp involvement in a deciduous tooth. The treatment was effective in 16 children and for the remaining two the restorative treatment was performed. Conclusion: The prevalence of white spot lesions found in enamel was $3.95 \%$, with a higher prevalence in females. Regarding predisposing factors, most children had some infectious diseases and frequently took antibiotics and anti-inflammatory drugs. The permanent right upper central incisor was the most affected. The treatment proved to be effective in most children possibly because the lesion is located more superficially in the enamel.

\section{KEYWORDS}

Dental enamel; Enamel hypoplasia; Tooth demineralization; Enamel microabrasion.

\section{RESUMO}

Objetivo: Determinar a prevalência, os fatores predisponentes de manchas brancas no esmalte dentário e a eficácia do tratamento pela técnica de microabrasão. Método: Foi desenvolvido um estudo em crianças na faixa etária dos 6 aos 12 anos de ambos os gêneros, matriculados em 3 escolas públicas municipais. Questionário epidemiológico foi aplicado aos participantes e aos pais ou responsáveis para investigar os fatores predisponentes das lesões em dentes permanentes durante a dentição mista. Realizou-se o exame bucal das crianças e nas que foram constatadas lesões de mancha branca foi proporcionado o tratamento odontológico pela técnica de microabrasão, nos incisivos e/ou primeiros molares permanentes, impedindo a evolução para uma lesão de cárie com cavitação, uma vez que a estrutura do esmalte estava danificada. Resultados: A maioria da amostra apresentou de $1 \%$ a $24 \%$ do esmalte atingido pelas manchas brancas. Os possíveis fatores etiológicos das manchas brancas foram infecções sistêmicas, trauma ou cárie com envolvimento pulpar em dente decíduo. O tratamento foi eficaz em 16 crianças e em duas restantes foi realizado o tratamento restaurador. Conclusão: A prevalência de lesões de manchas brancas encontradas em esmalte foi 3.95\% com maior predominância no gênero feminino. Com relação aos fatores predisponentes, a maioria das crianças tiveram algumas doenças infecciosas e fizeram uso de antibióticos e anti-inflamatórios. $\mathrm{O}$ incisivo central superior direito permanente foi o mais acometido. O tratamento mostrou-se eficaz na maioria das crianças, possivelmente devido à localização da lesão ser superficial no esmalte.

\section{PALAVRAS-CHAVE}

Esmalte dentário; Hipoplasia de esmalte; Desmineralização dentária; Microabrasão do esmalte. 


\section{INTRODUCTION}

T $\mathrm{n}$ the psychosocial scenario, aesthetics is an 1 important condition in life in society and behavior in relation to the other, having a direct relationship with self-image and self-esteem. In this way, the presence of white spots on enamel (WSE) has a negative psychological impact, especially on the anterior teeth, due to the anti-aesthetic appearance. In these individuals, the circumstances that affect the teeth in an unfavorable manner weigh on personality development and may even contribute to antisocial behavior $[1,2]$.

White spots may arise due to the incomplete or defective formation of the enamel during the formation of the dental germ, called enamel hypoplasia, causing a deficiency in its quantity and quality $[3,4]$. They may be associated with nutritional factors, excessive consumption of acidic drinks that cause erosion in dental enamel, high ingestion of fluoride (fluorosis), successive infections in early childhood during the calcification of crowns of permanent teeth or represent incipient caries, the mineral content and structural organization modified [2].

The diagnosis is complex, requiring detailed clinical examination, checking the location and distribution of these patches, as well as the patient's clinical history. The anamnesis is indispensable in the search for probable disorders or systemic diseases that may have affected the patient, as well as the ingestion of fluorides and also the family conditions that could determine defects in the enamel structure $[5,6]$.

The white spot is related to the loss of mineral by the enamel, but if diagnosed in its initial phase, it is partially demineralized and remineralized. Procedures for the purpose of removing stains on the teeth have been quite requested. Among them, it is possible to mention the technique of enamel microabrasion, obtaining aesthetically more acceptable results [7-12].

The technique consists in the superficial wear of the dental enamel by means of the joint action of a compound of acidic $\mathrm{pH}$ associated to abrasive particles that are applied to the altered surface, with mechanical pressure using rubber cup coupled to a micromotor of low rotation, which will promote the abrasion of enamel [13]. In spite of promoting wear, this technique reaches only part of the total enamel thickness. It is recommended as the first option for the management of teeth with intrinsic stains, as it removes opaque, brown spots and smoothes irregularities, ensuring a more regular and glossy surface that accentuates with time $[12,14]$.

It is a conservative technique that removes only a small portion of the surface layer of the enamel by the action of abrasive agents. It is considered ideal because it does not cause damage to the pulp and periodontal tissues and because it is inexpensive. Clinically, teeth submitted to microabrasion have presented satisfactory and permanent results in a short clinical period without discomfort for the patient $[11,15]$.

In the literature there is a history of traumas in deciduous teeth and successive systemic infections in childhood, and there is a correlation with enamel defects. Besides, the presence of WSE is also suggestive of early caries lesion, fluorosis or imperfect amelogenesis [16]. Based on this, it was decided to carry out this research to evaluate the presence of lesions of white spots on dental enamel in schoolchildren, emphasizing preventive, curative and control measures.

The purpose of this study was to determine the prevalence, predisposing factors of white spots on enamel and the effectiveness of treatment using the microabrasion technique.

\section{METHOD}

A cross-sectional observatory study was developed. The reference population consisted of children aged 6 to 12 years in the mixed dentition of both genders, a student at the São Francisco dos Capuchinhos School, Fontes Ibiapina Municipal School and Caio Passos de Parnaíba-Piauí Municipal School. Three 
municipal schools were chosen by lot among 8 in which the children who studied had the age group chosen for the research that was approved by the Research Ethics Committee of the State University of Piauí - CEP / UESPI, under opinion 1.377.015 .

The sample calculation was based on the target population: children from the city of Parnaíba, attending elementary school in 14 state public schools, choosen by lot, in 2017, totaling 6.540 students. Thus, in order to successfully achieve the objective of the present study, it was based on the survey by the Brazilian Institute of Geography and Statistics, which estimates an estimated 15.500 people in the target population: children living in the city of Parnaíba-Pi aged 6 to 12 years. According to the sample calculation, 374 children should be examined, but it was decided not to use it because it was less than the number of children in the age group of the study that were enrolled in the three schools.

In this way a total of 456 children were included because there would also be a possibility of giving up the research. As inclusion criteria were included, all children aged between 6 and 12 years, corresponding to the period of the mixed dentition, with at least one first permanent molar or permanent central incisor completely erupted, with one or more deciduous teeth missing, whose parents or guardians and the children had accepted the research. And as exclusion criteria, children under 6 years of age, as well as children over 12 years of age and those whose parents or guardians did not authorize the research.

The calibration of the team, consisting of two researchers, was carried out during 36 $\mathrm{h}$, divided into theoretical discussion of the variables used, codes and criteria of examination and practical discussion, simulating the different conditions and situations that the professionals would encounter during the practical work for diagnosis of WSE lesions, according to the methodology described in another publication [17]. In order to assess intra- and inter- examiner diagnostic reproducibility, $10 \%$ of the total sample was double-checked by each of the examiners, with the Kappa coefficient for intraand inter-examiner agreement being 0.81 and 0.82 , respectively.

Epidemiological questionnaire was applied to the participants and caregivers to investigate the etiological factors that caused the appearance of WSE on permanent teeth during the mixed dentition. Oral examination was carried out at the school to analyze the presence of WSE visually detected lesions and the need for treatment, using natural light, using gloves of procedures and wooden spatula. For clinical examination, the teeth were dry with sterile gauze on all faces and when there was a white spot were recorded in an odontogram.

A pre-established sequence followed and analyzed the Dental Enamel Development Defects (DDE) by dental group of the upper arch and lower arch. They were classified according to opacity, hypoplasia, and others (teeth that could not be examined, lost, or erupted). It was also used, as a differential diagnosis, the shape of the lesion found and the location, since white spots in the cervical region, close to the gingiva and in the shape of a half moon, opaque or not, were characterized as caries lesions [18].

For those children in whom WSE lesions were found, dental treatment was provided by the microabrasion technique and at the end of each session, neutral sodium fluoride was applied for 1 minute, in order to prevent the evolution to a caries lesion with cavitation, once the enamel structure was damaged. In order to avoid recurrence, the treated children were monitored monthly for 12 months, being instructed on oral hygiene, and should be supervised by their parents or guardians.

After a previous appointment with the parents, the children were attended at the Clinical School of Dentistry (DSC) of the State University of Piauí. The dental treatment was performed by the microabrasion technique with pumice stone and 37\% phosphoric acid, with the aid of a rubber cup. Two applications of 15 
s per session, with a 5 minutes interval between the two applications, totaling 5 sessions for each tooth, in the enamel region affected by the white spot. Smears of the prepared solution were made with rubber cup, but care is taken to wash and dry in the interval between each application. The treatment was performed once a week, totaling 5 weeks $[13,14]$, with standardized intraoral photographs obtained with a digital camera (Canon model EOS 450 D) before and after each session.

The lesions were photographed and the JPEG digital images were processed in the Image $\mathrm{J}$ software to determine the ESW area in $\mathrm{mm}^{2}$. The criteria for evaluation of the dental surface area affected by the white spot were made through the explicit in Table 1 , in which 0 was considered as indicative of dental enamel not affected by ESW and 1 to $4 \mathrm{~mm}^{2}$ with impairment in the structure with their respective percentages (Table I).

Table I - Index and percentage of dental surface affected by white spot on enamel.

\begin{tabular}{|cc|}
\hline Index & Percentage of dental area affected $(\mathbf{m m})^{2}$ \\
\hline 0 & $0 \%$ \\
\hline 1 & $1 \%-24 \%$ \\
\hline 2 & $25 \%-49 \%$ \\
\hline 3 & $50 \%-74 \%$ \\
\hline 4 & $75 \%-100 \%$ \\
\hline
\end{tabular}

With the SPSS, in its version 21, the prevalence of lesions in the teeth of the children was obtained. The Chi-square test was applied to find out a statistically significant difference between the gender and presence of WSE.

\section{RESULTS}

A total of 456 children were examined, $48 \%$ male $(n=219)$ and $52 \%$ female $(n=237)$. The prevalence rate of WSE lesions was 3.95\% in 18 children, $55.5 \%$ of the female gender (n $=10)$ and $44.5 \%$ of the male gender $(n=8)$. From the statistical calculation $\mathrm{X}^{2}$ (Chi-Square), there was a statistically significant difference between the gender of participants $\mathrm{X}^{2}(1)=$ $3.967, \mathrm{p}<0.05$, indicating that the girls were the most affected with lesions in enamel.

Ninety teeth presented the lesions. The most affected teeth were the permanent upper central incisors and posterior permanent teeth were not affected. In the 18 children, the upper right central incisor was affected and they had at least 2 teeth with WSE. In 15 children, there were lesions to the upper central incisors (Figure $1)$.

The largest number of children affected by WSE was at the age of 10 years ( Figure 2).

In relation to the dental enamel surface area affected by WSE, most had 1 to $24 \%$ of the enamel involved $(\mathrm{n}=11)$, score 1 (Table 1$)$, (Figure 3).

Predisposing factors of WSE were shown after applying the questionnaire to parents / guardians. Twelve of 18 children had some type of infectious disease and 16 of them frequently took antibiotics and anti-inflammatory drugs (AINs) (Figure 4).

Initial and final photos showing white spot on the vestibular of the right upper central incisor treated with microabrasion technique were shown in figures 5 and 6.

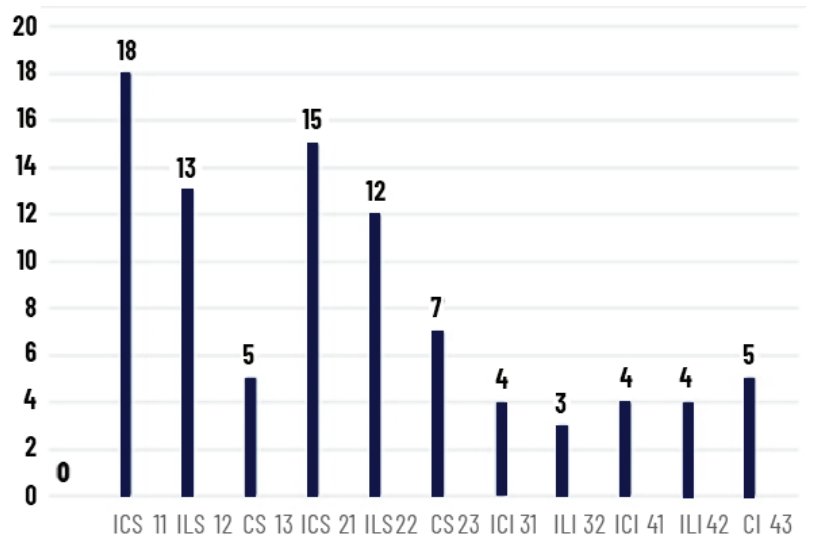

Figure 1 - Distribution of affected teeth and number of lesions. 


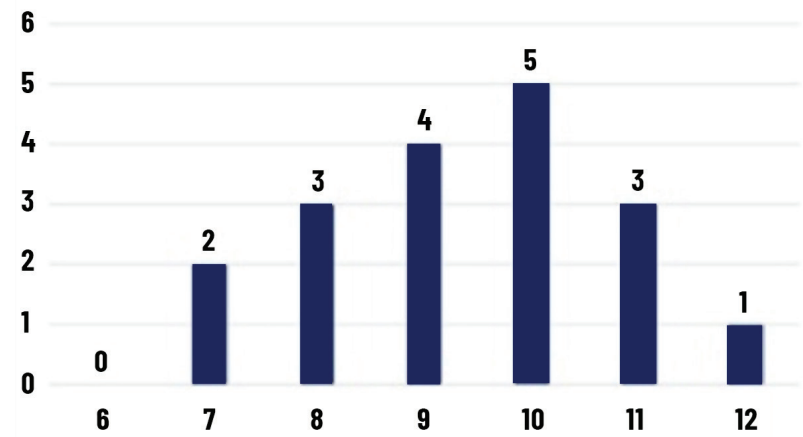

Number of schoolchildren affected by white spots according to age.

Figure 2 - Distribution of schoolchildren affected by white spots according to age.

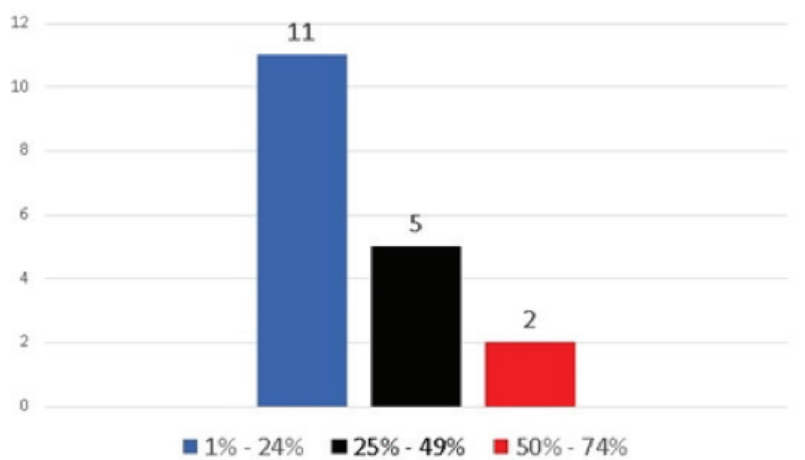

Figure 3 - Average area of dental surface affected by white spots.

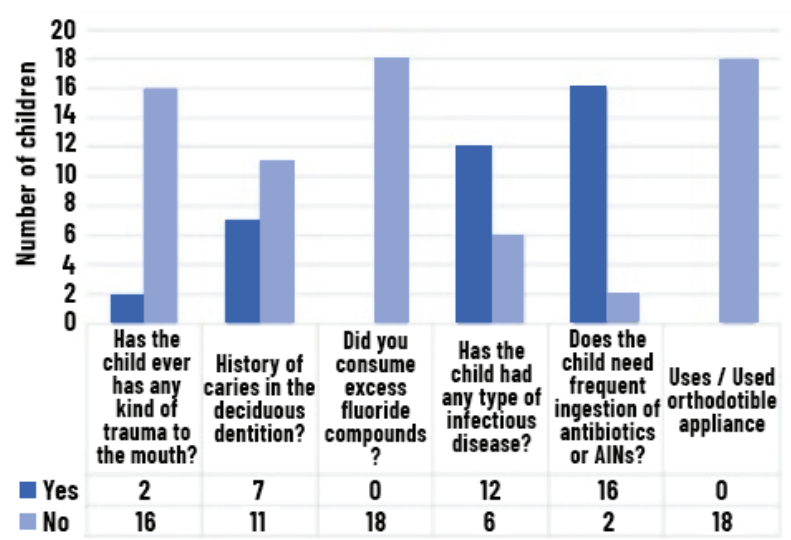

Figure 4 - Questionnaire applied to parents / guardians about etiological factors.

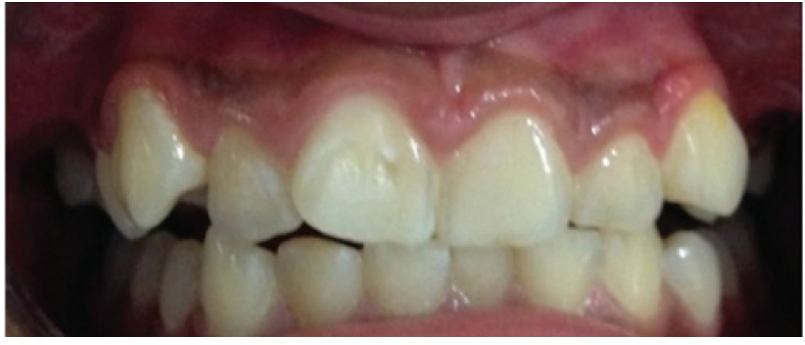

Figure $\mathbf{5}$ - Initial photo showing white spot on the vestibular of the right upper central incisor.

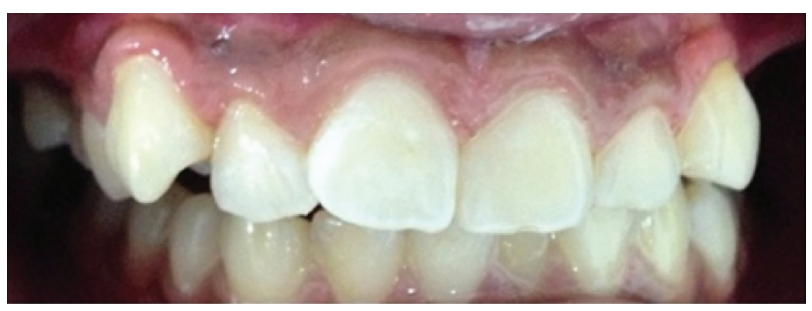

Figure 6 - Final photo after treatment with microabrasion technique.

\section{DISCUSSION}

The prevalence of WSE was 3.95\%, with predominance in the female gender, not corroborating the studies of other authors $[18,19]$ whose prevalence was $33.3 \%$ and $34.1 \%$, respectively, with no difference between genders.

The most affected teeth were the permanent upper central incisors. A similar result was observed by Hoffman et al. [20] whose occurrence of these failures reached in $25 \%$ of the upper incisors versus $10.1 \%$ of the lower incisors.

Regarding predisposing factors of WSE in this study, the excessive intake of antibiotics and AINs, successive systemic infections, trauma or caries in the deciduous dentition with pulp necrosis suggest that they are responsible for the appearance of WSE. It should be emphasized that the sugar contained in the composition of the antibiotic combined with poor oral hygiene may be responsible in this case, as reported by CorrêaFaria et al. [21]. In the period of childhood (approximately 3 weeks to 12 months of life) 2/3 of the enamel hypoplasias occur. 
This period is considered critical because the resistance of children to disease is diminished. In the period of early childhood (from the 13th to the 34th month of life) is when the permanent lateral incisors, the first and second premolars are formed and calcified. Approximately $1 / 3$ of enamel hypoplasias occur in this period [19]. For Shreiner et al. [18] the WSE has a varied etiology and different characteristics, being the one caused by the fluorosis that had the highest prevalence index.

The treatment performed in the 18 children with WSE was more effective in 16 , probably because the microabrasion technique is indicated for the removal of superficial irregularities and intrinsic spots, since they are located in the more superficial layers of dental enamel [12-16].

It is worth mentioning that after the treatment the microabrasionated teeth may acquire a darker or yellowish coloration, due to the remaining enamel surface remaining thinner, showing a more intense dentin tissue, which can determine, therefore, a more yellowish color to the elements [7].

Another feature of recently microdegraded surfaces by this technique is the socalled "abrasive effect", in which the optical properties camouflage the remaining subsurface stains when light is reflected by this surface and refracted through it, giving a glaze to the enamel $[7,12]$.

Aesthetic improvement in most cases can be given by removing the porous surface of the enamel exposing the deeper layer of the enamel, which contains many sites available for remineralization. The rapid incorporation of minerals promotes the growth of the crystals of the enamel that results in the reduction of the pores and progressively in a smooth and shiny enamel [2].
In two patients, no significant improvement was observed, suggesting that the spots were intrinsic and more pronounced, and another form of treatment, the restoration with composite resin, was suggested by Peruchi et al. [11] and by Sandfeld et al. [12].

Regarding the location, WSE can affect a single or several teeth, or a group of developing teeth, or even the entire dental arch, but the highest prevalence is in the upper incisors $[6,8]$.

In eleven of the eighteen treated cases the lesions were located in the incisal third. This region presents greater thickness of enamel and absence of dentin tissue between buccal and lingual dental enamel. Whay and Welbury [22] showed that remaining incisal enamel may exhibit excessive translucency, as well as greater brittleness to wear and fracture over time.

In five children WSE was found on both the incisal edge and the middle third of the teeth, and the microabrasion treatment was probably successful because the lesion must have reached only the outer surface of the enamel [12$14,16,21,22]$.

The evidence from the present study indicates a great and urgent need for knowledge of factors associated with WSE. From the data revealed, the aspects of preventive education and oral hygiene must be taken into consideration.

Early diagnosis of these lesions will allow both the monitoring of these teeth and the indication of preventive, targeted and effective measures that can be put in place before caries disease to appear.

However, despite major advances in scientific knowledge regarding the causes of enamel defects, further research is required in order to translate the knowledge gained in the basic sciences research to accurate clinical diagnosis and successful treatment of the white spots. 


\section{CONCLUSION}

The prevalence of lesions of white spots found in dental enamel was 3.95\%, with a higher prevalence in the female gender. The permanent right upper central incisor was the most affected.

Regarding the predisposing factors of white spots on enamel, most children had some type of infectious disease and frequently took antibiotics and anti-inflammatory drugs.

The treatment proved to be effective in most children possibly because the lesion is located more superficially in the enamel.

It was suggested the use of remineralizing substances with fluorides as an alternative to repair lesions that have not been removed with enamel microabrasion.

\section{REFERENCES}

1. Ramos CJ, Myaki SI, Shintome LK, Chavez VEA. Effects of microabrasion on white spot of inactive caries on deciduous teeth. Pesq Bras Odontoped Clin Integr. 2006;6(2):149-54.

2. Queiroz VAO, Martins GC, Grande CZ, Gomes JC, Campanha NH, Jorge JH. Report of two microabrasion techniques of enamel for stain removal: discussion of clinical cases. Rev Odontol UNESP. 2010;39(6):369-72.

3. Worschhech CC, Aguiar FHB, Maia DS, Lovadino JR, Martins LRM. Partial direct facet as aesthetic and conservative treatment of enamel pathologies: reports of clinical cases. JBD. 2003;2(7):247-53.

4. Souza JB, Rodrigues PCF, Lopes LG, Guilherme AS, Freitas GC, Moreira FCL. Enamel hypoplasia: aesthetic restorative treatment. Rev Odont Bras Central. 2009;18(47):14-19.

5. Seow WK. Developmental defects of enamel and dentin: challenges for basic science research and clinical management. Aust Dent J. 2014 Oct:59(1):143-154. doi: 10.1111/adj.12104.

6. Macri D, Fagan J. Implement a minimally invasive approach. Dimensions of Dental Hygiene. 2016 Feb.14(3):32-37.

7. Croll TP, Helpin ML. Enamel microabrasion: a new approach. J Esthet Rest Dent. 2000;12(2):64-71. doi: 10.1111/j.1708-8240.2000.tb00202.x.
8. Kwon SR, Wertz PW. Review of the mechanism of tooth whitening. J Esthet Restor Dent. 2015 Sep-0ct;27(5):240-257. doi:10.1111/jerd.12152.

9. Knösel M, Eckstein A, Helms HJ. Durability of esthetic improvement following Icon resin infiltration of multibracket-induced white spot lesions compared with no therapy over 6 months: a single-center, splitmouth, randomized clinical trial. Am J Orthod Dentofacial Orthop. 2013 June;144:86-96. doi: 10.1016/j.ajodo.2013.02.029.

10. Elkhazindar MM, Welbury RR. Enamel microabrasion. Dent Upolate. 2000; 27(5):194-96

11. Peruchi CMS, Bezerra ACB, Azevedo TDPL, SILVA EB. The use of enamel microabrasion for the removal of white spots suggestive of dental fluorosis: clinical case. Rev Odontol Arac. 2004; 25(2):72-77.

12. Sundfeld RH, Rahal V, Croll TP,DE Aalexandre RS, Briso ALF. Enamel microabrasion followed by dental bleaching for patients after orthodontic treatment-case reports. J Esthet Restor Dent. 2007 0ct;19(2):71- 77. doi: 10.1111/j.1708-8240.2007.00069.x.

13. Pini NIP, Lima DANL, Ambrosano GMB, Da Silva WJ, Aguiar FHB, Lovadino JR. Effects of acids used in the microabrasion technique: Microhardness and confocal microscopy analysis. J Clin Exp Dent. 2015; 7(4): e506-e512.

14. Pini NIP, Sundfeld-Neto D, Aguiar FHB, Sundfeld RH, Martins LRM, Lovadino JR, Lima DANL. Enamel microabrasion: An overview of clinical and scientific considerations. World J Clin Cases. 2015 Jan; 3(1):34-41. doi: 10.12998/wjcc.v3.1.34

15. Pandey P, Ansari AA, Moda P, Yadav M. Enamel microabrasion for aesthetic management of dental fluorosis. BMJ Case Rep. 2013; 11:1-3.

16. Khoroushi M, Kachuie M. Prevention and Treatment of White Spot Lesions in Orthodontic Patients. Contem. Clin. Dent. 2017 Jan-Mar;8(1):11-18. doi: 10.4103/ccd.ccd 216 17.

17. Peres MA, Traebert J, Marcenes W. Calibration of examiners for dental caries epidemiology studies. Cad Saúde Pública. 2001; 17(1):153-59.

18. Shreiner CC, Rocha JC. Prevalence and location of white spots on dental enamel in schoolchildren from the Municipality of São José dos Campos. Rev ABO. 2003; 11(5):293-98.

19. Machado CAA, Costa BR, Gomes LRG, Fragelli CMB. Prevalence and etiology of enamel development defects in deciduous and permanent teeth. Rev UNINGÁ. 2013;15(1):48-54.

20. Hoffmann RHS, Sousa MLR, Cyoriano S. Prevalence of enamel defects and their relationship with dental caries in deciduous and permanent dentitions. Cad Saúde Públ. 2007; 23(2):435-44. doi: 10.1590/S0102311X2007000200020.

21. Corrêa-Faria P,Martins-Júnior PA, Vieira-Andrade RG, Oliveira-Ferreira F, Marques LS, Ramos-Jorge ML. Developmental defects of enamel in primary teeth: prevalence and associated factors. Inter J Paediatric Dent. 2012 Apr; 23(3):173-79. doi: 10.1111/j.1365-263X.2012.01241.X

22. Wray A, Welbury R. Treatment of intrinsic discoloration in permanent anterior teeth in children and adolescente. Int J Paediatric Dent. 2008 July; 11(4):309-315. doi: 10.1046/j.1365-263X.2001.00300.x.

Dra. Ana de Lourdes Sá de Lira (Corresponding address)

Universidade Estadual do Piauí, Faculdade de Odontologia Rua Senador Joaquim Pires 2076 Ininga. Teresina-PI-Brasil E-mail: anadelourdessl@hotmail.com

Date submitted: 2020 Feb 07 Accept submission: 2020 Apr 20 